\title{
Tingkat Pendidikan Dan Pengetahuan Masyarakat Dengan Tindakan Pencegahan Penularan Covid-19
}

\author{
Adi Yeremia Mamahit ${ }^{1(\mathrm{CA})}$, Ariska ${ }^{2}$ \\ ${ }^{1(\mathrm{CA})}$ Fakultas Keperawatan, Universitas Pembangunan Indonesia, Manado, Indonesia; \\ adiwork88@gmail.com \\ (Corresponding Author) \\ ${ }^{2}$ Fakultas Keperawatan, Universitas Pembangunan Indonesia, Manado, Indonesia
}

\begin{abstract}
The rapid spread of the Covid-19 disease, one of the contributing factors is the lack of public knowledge about this disease, most villagers do not use masks in their daily activities, do not keep their distance in communication, and most houses do not have a handwashing station in front of them. houses like in the surrounding villages. The purpose of this study was to determine the relationship between the level of education and public knowledge about Covid-19 with preventive measures for the transmission of Covid19 in South Tumani Village, South Minahasa Regency. This research is a type of descriptive analytic research with a cross sectional study design. The population in this study were all adults totaling 496 people from 230 families, the sample size of 222 adults obtained based on calculations using the Slovin formula. The results of the study based on statistical tests using the Chi-Square between the education level variable and the Covid-19 preventive action variable obtained a $\mathrm{p}$ value $=0.000(<\mathrm{a}=0.05)$, similar results were obtained between the community knowledge variable about Covid-19 and preventive measures. Covid-19 with $\mathrm{p}$ value $=0.000(<\mathrm{a}=0.05)$. The conclusion is that there is a significant relationship between the level of education and the prevention of Covid-19 transmission. There is a significant relationship between public knowledge about Covid-19 and preventive measures for Covid-19 transmission.
\end{abstract}

Keywords: Education Level; Public Knowledge; Covid-19 Prevention

\begin{abstract}
ABSTRAK
Penyebaran penyakit Covid-19 yang begitu cepat salah satu faktor penyebabnya ialah pengetahuan masyarakat mengenai penyakit ini yang kurang, kebanyakan penduduk desa tidak menggunakan masker dalam aktivitas sehari-hari, tidak menjaga jarak dalam komunikasi, serta sebagian besar rumah tidak memiliki tempat cuci tangan di depan rumah seperti pada desa-desa sekitar. Tujuan penelitian ini ialah untuk mengetahui hubungan tingkat pendidikan dan pengetahuan masyarakat mengenai Covid-19 dengan tindakan pencegahan penularan Covid-19 di Desa Tumani Selatan Kabupaten Minahasa Selatan. Penelitian ini merupakan jenis penelitian deskriptif analitik dengan rancangan cross sectional study. Populasi pada penelitian ini ialah seluruh orang dewasa yang berjumlah 496 orang dari 230 keluarga, besar sampel sebanyak 222 orang dewasa yang didapatkan berdasarkan perhitungan dengan menggunakan rumus Slovin. Hasil penelitian berdasarkan uji statistik dengan menggunakan Chi-Square antara variabel tingkat pendidikan dan variabel tindakan pencegahan Covid-19 didapatkan nilai $p=0,000$ $(<a=0,05)$, hasil yang serupa didapatkan antara variabel pengetahuan masyarakat mengenai Covid-19 dengan tindakan pencegahan Covid-19 dengan nilai $p=0,000(<a=0,05)$. Kesimpulan ada hubungan yang signifikan antara tingkat pendidikan dengan tindakan pencegahan penularan Covid-19. Ada hubungan yang signifikan antara pengetahuan masyarakat mengenai Covid-19 dengan tindakan pencegahan penularan Covid-19.
\end{abstract}

Kata Kunci : Tingkat Pendidikan; Pengetahuan Masyarakat; Pencegahan Covid-19 


\section{PENDAHULUAN}

Pada 5 Januari 2020 World Health Organitation (WHO) menerbitkan pertama kali informasi mengenai wabah penyakit dengan virus baru di Wuhan, pada 30 Januari WHO mengumumkan bahwa wabah tersebut merupakan darurat kesehatan masyarakat, wabah ini menyebar ke negara-negara sekitar bahkan ke seluruh dunia yang menyebabkan akses bandara diberbagai negara ditutup dan beberapa negara menerapkan kebijakan lockdown, wabah tersebut dinamakan Corona Virus Desease "Covid-19" (WHO, 2020).

Jumlah kasus Covid-19 secara global yang terkonfirmasi pada 24 Oktober 2020 berjumlah 42,055,863 jiwa di seluruh dunia dan total yang meninggal sebanyak 1,141,567 jiwa. Jumlah kasus paling banyak berada di Amerika Serikat dengan jumlah 8,320,941 jiwa dan Amerika Serikat juga merupakan negara dengan angka jumlah kematian paling banyak yaitu 221,564 jiwa dan Indonesia berada pada urutan ke 19 (WHO, 2020). Berdasarkan rilis Satgas Covid-19 Indonesia pada 24 Oktober 2020 jumlah kasus terkonfirmasi di Indonesia sebanyak 389,712 ribu jiwa dan yang meninggal 13,299 jiwa dengan laporan terakhir 24 jam sebanyak 118 orang meninggal (Satgas Covid-19 Nasional, 2020).

Saat ini di Provinsi Sulawesi Utara dalam situs resmi pemerintah provinsi pada 24 Oktober 2020 jumlah yang terkonvirmasi positif Covid-19 sebanyak 5,176 ribu jiwa dengan jumlah yang dirawat di Rumah Sakit sebanyak 607 jiwa, pasien sembuh 4,374 jiwa dan pasien yang meninggal sebanyak 195 jiwa (Dinkes Provinsi Sulawesi Utara, 2020). Jumlah positif paling banyak berada di Kota Manado dengan jumlah 2,273 pasien, sedangkan untuk Kabupaten Minahasa Selatan berada pada urutan ke enam dari 17 kabupaten kota dengan jumlah yang terkonfirmasi positif Covid-19 sebanyak 200 orang, yang saat ini dirawat ada 17 orang, pasien sembuh 171 orang dan pasien yang meninggal 12 orang (Satgas Covid19 Provinsi Sulawesi Utara, 2020).

Penyebaran penyakit Covid-19 yang begitu cepat salah satu faktor penyebabnya ialah pengetahuan masyarakat mengenai penyakit ini yang kurang. Penelitian dari Omah at al (2020) mengenai kajian pengetahuan, persepsi, dan respons tentang Covid-19 penyebaran komunitas diantara populasi dunia, menemukan orang dengan pengetahuan yang menyeluruh tentang penyakit sesuai dengan informasi yang tersedia sehat dan tidak terinfeksi. Penelitian dari Pradono dan Sulistyowati (2013) menemukan ada hubungan positif yang signifikan antara pengetahuan tentang kesehatan, perilaku hidup sehat, dan tingkat pendidikan dengan status kesehatan. Penelitian lain dari Moudy dan Syakurah (2020) menemukan terdapat variasi pada tingkat pengetahuan masyarakat Indonesia terhadap COVID-19, pengetahuan mengenai berbagai topik mengenai COVID-19 memiliki rentang yang besar yaitu 26,9\%96,6\% pada masyarakat di Indonesia.

Desa Tumani Selatan Kecamatan Maesaan Kabupaten Minahasa Selatan memiliki total keluarga sebanyak 230 dengan jumlah penduduk dewasa sebanyak 496 jiwa. Beberapa tahun terakhir banyak anak muda di desa ini yang bisa melanjutkan sekolah ke tingkat perguruan tinggi dengan memanfaatkan beasiswa pemerintah baik pusat maupun daerah, oleh karena hal ini menyebabkan tingkat pendidikan di Desa Tumani Selatan menjadi beragam. Berdasarkan observasi yang telah dilakukan peneliti kebanyakan 
penduduk desa tidak menggunakan masker dalam aktivitas sehari-hari serta sebagian besar rumah tidak memiliki tempat cuci tangan di depan rumah seperti pada desa-desa di sekitar.

Tujuan yang akan dicapai dari penelitian ini ialah untuk mengetahui hubungan tingkat pendidikan dan pengetahuan masyarakat mengenai Covid-19 dengan tindakan pencegahan penularan Covid-19 di Desa Tumani Selatan Kabupaten Minahasa Selatan. Urgensi penelitian, tindakan pencegahan penularan Covid-19 yang banyak disepelehkan oleh masyarakat desa meski telah mengetahui apa itu Covid-19 dan cara penularannya.

\section{METODE}

Penelitian ini merupakan jenis penelitian deskriptif analitik dengan rancangan cross sectional study. Populasi pada penelitian ini ialah seluruh orang dewasa di Desa Tumani Selatan yang berjumlah 496 orang dari 230 keluarga. Orang dewasa dengan usia diatas samadengan delapan belas tahun dianggap cukup mengerti dalam menerima informasi dari berbagai sumber informasi, dan diaggap relefan dalam penilaian untuk variabel pengetahuan dan tingkat pendidikan. Berdasarkan perhitungan dengan menggunakan rumus Slovin didapatkan jumlah sampel pada penelitian ini ialah 222 orang dewasa. Teknik pengambilan sampel pada penelitian ini menggunakan teknik acak sederhana dengan jenis tabel acak.

Data pada penelitian ini ialah data primer dan data sekunder, untuk data primer berupa tingkat pendidikan dan pengetahuan mengenai Covid-19 responden didapatkan melalui lembar kuesioner yang ditanyakan pada responden, dan untuk tindakan pencegahan penularan Covid-19 selain menggunakan lembar kuesioner peneliti juga melakukan observasi pada responden. Data sekunder pada penelitian ini ialah jumlah keluarga dan penduduk dewasa yang didapatkan dari pemerintah Desa Tumani Selatan. Analisis data univariat pada penelitian ini ialah tingkat pendidikan, pengetahuan responden mengenai Covid-19, dan bentuk-bentuk tindakan pencegahan penularan Covid-19 responden yang akan disajikan dalam tabel

\section{HASIL}

Tabel 1. Karakteristik Responden Masyarakat Desa Tumani Selatan, Kabupaten Minahasa Selatan

\begin{tabular}{clcc}
\hline No & Karakteristik Responden & Jumlah $(\mathrm{n}=222)$ & Persentase $(\%)$ \\
\hline 1 & Kelompok Umur & & \\
& 18-25 tahun & 80 & 36,0 \\
& $26-35$ tahun & 88 & 39,6 \\
& $36-45$ tahun & 32 & 14,4 \\
& $46-55$ tahun & 12 & 5,4 \\
& $56-65$ tahun & 8 & 3,6 \\
& $>65$ tahun & 2 & 1,0 \\
\hline
\end{tabular}




\begin{tabular}{llcc}
\hline No & Karakteristik Responden & Jumlah $(\mathrm{n}=222)$ & Persentase (\%) \\
\hline 2 & Jenis Kelamin & 128 & \\
& Laki-laki & 94 & 57,7 \\
& Perempuan & & 42,3 \\
3 & Pendidikan & 33 & \\
& Pendidikan Tinggi & 161 & 14,9 \\
& Pendidikan Menengah & 28 & 72,5 \\
& Pendidikan Rendah & & 12,6 \\
\hline
\end{tabular}

Berdasarkan tabel 1 dapat diketahui bahwa umur responden sebagian besar berada pada kelompok 26 - 35 tahun, sebagian besar berjenis kelamin laki-laki, dengan tingkat pendidikan yang terbanyak adalah Pendidikan menengah.

Tabel 2. Distribusi frekuensi Pengetahuan dan Tindakan pencegahan Covid-19 pada masyarakat Desa Tumani Selatan, Kabupaten Minahasa Selatan.

\begin{tabular}{clcc}
\hline No & Kriteria & Jumlah $(\mathrm{n}=222)$ & Persentase $(\%)$ \\
\hline 1 & Pengetahuan mengenai Covid-19 & & \\
& Baik & 190 & 85,6 \\
& Tidak baik & 32 & 14,4 \\
\multirow{2}{*}{2} & Tindakan Pencegahan & & \\
& Baik & 186 & 83,8 \\
& Tidak baik & 36 & 16,2 \\
\hline
\end{tabular}

Tabel 2 menggambarkan tingkat pengetahun responden mengenai Covid-19 terbanyak pada kategori pengetahuan baik, begitu pula dengan tindakan pencegahan sebagian besar pada kategori baik.

Tabel 3. Hubungan tingkat pendidikan dengan tindakan pencegahan covid-19 pada masyarakat Desa Tumani Selatan, Kabupaten Minahasa Selatan.

\begin{tabular}{|c|c|c|c|c|c|c|c|}
\hline \multirow{3}{*}{ Tingkat Pendidikan } & \multicolumn{4}{|c|}{ Tindakan Pencegahan Covid-19 } & \multirow{3}{*}{ Total } & \multirow{3}{*}{$\%$} & \multirow{3}{*}{ Nilai $\rho$} \\
\hline & \multicolumn{2}{|c|}{ Baik } & \multicolumn{2}{|c|}{ Tidak Baik } & & & \\
\hline & $\mathrm{n}$ & $\%$ & $\mathrm{n}$ & $\%$ & & & \\
\hline Tinggi & 32 & 17,2 & 1 & 2,8 & 33 & 14,9 & \\
\hline Menengah & 149 & 80,1 & 12 & 33,3 & 161 & 72,5 & \\
\hline Rendah & 5 & 2,7 & 23 & 63,9 & 28 & 12,6 & 0,000 \\
\hline Total & 186 & 100 & 36 & 100 & 222 & 100 & \\
\hline
\end{tabular}

Tabel 3 menggambarkan hubungan tingkat pendidikan dengan tindakan pencegahan covid-19, dimana responden dengan tingkat Pendidikan menengah memiliki Tindakan pencegahan yang baik $(80,1 \%)$ dengan $p$-value 0,000 . 
Tabel 4. Hubungan pengetahuan mengenai Covid-19 dengan tindakan pencegahan covid-19 pada masyarakat Desa Tumani Selatan, Kabupaten Minahasa Selatan.

\begin{tabular}{|c|c|c|c|c|c|c|c|}
\hline \multirow{3}{*}{$\begin{array}{l}\text { Pengetahuan mengenai } \\
\text { Covid-19 }\end{array}$} & \multicolumn{4}{|c|}{ Tindakan Pencegahan Covid-19 } & \multirow{3}{*}{ Total } & \multirow{3}{*}{$\%$} & \multirow{3}{*}{ Nilai $\rho$} \\
\hline & \multicolumn{2}{|c|}{ Baik } & \multicolumn{2}{|c|}{ Tidak Baik } & & & \\
\hline & $\mathrm{n}$ & $\%$ & $\mathrm{n}$ & $\%$ & & & \\
\hline Baik & 185 & 99,5 & 5 & 13,9 & 190 & 85,6 & \\
\hline Tidak Tidak & 1 & 3,1 & 31 & 5,1 & 32 & 14,4 & 0,000 \\
\hline Total & 186 & 100 & 36 & 100 & 222 & 100 & \\
\hline
\end{tabular}

Berdasarkan tabel 4 diketahui pengetahuan mengenai Covid-19 dengan tindakan pencegahan covid-19, dimana responden dengan pengetahuan baik memiliki tindakan pencegahan yang baik $(99,5 \%)$ dengan $p$-value 0,000 .

\section{PEMBAHASAN}

\section{Tingkat pendidikan}

Tingkat pendidikan pada penelitian ini dibagi atas tiga tingkatan, yang pertama tingkat pendidikan tinggi ialah semua responden yang tamat pendidikan diploma dan sarjana, yang kedua ialah tingkat pendidikan menengah, yaitu responden yang tamat pendidikan Sekolah Menengah Pertama (SMP) dan Sekolah Menengah Atas (SMA, dan tingkat dasar ialah responden yang tamat Sekolah Dasar (SD) dan tidak sekolah. Berdasarkan analisis univariat, responden dengan tingkat pendidikan paling banyak ialah tingkat pendidikan menengah (72,5\%). Hasil pada penelitian ini sejalan dengan penelitian dari Khairunnisa dkk (2020) mengenai karakteristik masyarakat dengan perilaku pencegahan Covid-19 pada masyarakat dimana tingkat pendidikan responden yang paling banyak ialah tingkat menengah dengan persentase 80,6\%. Berdasarkan klasifikasi Al Amin (2017) sampel pada penelitian ini paling banyak ada pada kelompok usia remaja akhir dan dewasa mudah yaitu usia 18 sampai 35 tahun, dimana pada usia ini responden lebih sadar akan pendidikan dan pada masa sekarang banyak masyarakat berpendapat bahwa pendidikan itu perlu, seperti penelitian dari Ladaria (2020) dimana masyarakat berpendapat pendidikan merupakan hal yang wajib yang harus ditempuh, dengan masyarakat yang berpendidikan kemiskinan dapat berkurang.

\section{Pengetahuan}

Berdasarkan hasil penelitian ini mayoritas responden memiliki pengetahuan yang baik mengenai Covid-19 (85,6\%). Sejak Covid-19 bersatus pandemi global yaitu pada awal tahun 2020 informasi mengenai Covid-19 menjadi informasi yang paling banyak diberitakan pada tahun 2020, penelitian sebelumnya oleh Santoso dan Setyowati (2020) Media sosial menjadi sumber berita yang paling banyak diakses tentang Covid -19 seperti WhatsApp, Line, Instagram dan Facebook. Informasi yang tepat dan cepat dapat mempengaruhi seseorang untuk mengambil tindakan yang yang tepat. Penelitian lainnya oleh Yunus dan Zakaria (2021) sumber informasi yang dominan pada penelitian tersebut ialah media televisi. Meskupan merupakan masyarakat pedesaan akan tetapi masyarakat di Desa Tumani Selatan mengikuti 
informasi-informasi mengenai Covid-19 dari semua media informasi yang ada, hal ini sangat mempengaruhi pengetahuan dari responden pada penelitian ini. 14,4\% responden yang pengetahuannya tidak baik mengenai Covid-19 ialah responden yang mengangap Covid-19 bukanlah penyakit yang harus diwaspadai sehingga ada kecenderungan untuk tidak mencari informasi atau menyepelehkan informasi mengenai Covid-19 yang beredar, responden yang menganggap Covid-19 ialah penyakit yang harus diwaspadai akan tertarik dengan informasi mengenai Covid-19 penelitian sebelumnya oleh Suliswati at all (2020) responden banyak mencari informasi mengenai cara mencegah virus Covid-19, penularan di Indonesia, penyebab, pengobatan dan gejala.

\section{Tindakan Pencegahan}

Sebanyak 186 responden atau 83,8\% responden memiliki tindakan pencegahan Covid-19 yang baik, responden yang memiliki pencegahan yang baik menjadi dominan pada penelitian ini. Penelitian ini sejalan dengan penelitian sebelumnya oleh Puspitasari dan Septimar (2021) dimana dari 399 responden, 374 responden atau 93,7\% memiliki perilaku yang baik terhadap pencegahan Covid-19. Penelitian ini juga sejalan dengan penelitian Sukesih dkk (2021) dimana mayoritas responden memiliki perilaku pencegahan yang baik yaitu sebanyak 76,4\%. Pencegahan yang baik terhadap pencegahan Covid-19 tidak lepas dari pengetahuan responden yang baik mengenai Covid-19 (Muhtar et al., 2020), seperti halnya pada penelitian Mujiburrahman dkk (2021) dengan menggunakan uji korelasi Spearman mendapatkan $\mathrm{p}=0,001$ (nilai $\mathrm{p}<0,05$ ) yang artinya terdapat hubungan yang signifikan antara pengetahuan dengan perilaku pencegahan COVID-19.

\section{Hubungan tingkat pendidikan dengan Tindakan Pencegahan Covid-19}

Berdasarkan hasil uji statistik antara variabel tingkat pendidikan dan variabel tindakan pencegahan Covid-19 didapatkan nilai $p=0,000(<a=0,05)$ yang artinya terdapat hubungan yang signifikan antara tingkat pendidikan dan tindakan pencegahan Covid-19 pada masyarakat desa Tumani Selatan, Kecamatan Maesaan. Hasil penelitian ini sama dengan penelitian sebelumnya oleh Khairunnisa dkk (2020) yang mendapatkan nilai $p=0,000$ antara hubungan variabel pendidikan dengan perilaku pencegahan Covid-19. Pendidikan merupkan salah satu faktor utama dalam peningkatan pengetahuan, Purana (2017) Pengaruh positif terjadi apabila nilai-nilai dalam pendidikan dapat diterapkan sesuai dengan aturan-aturan atau norma-norma yang ada. Manusia secara ideal berdasarkan pengalaman dan perkembangannya telah mampu mengenali, memahami, menerima, mematuhi, bahkan telah mampu menjelmakan dan menampilkan norma kedewasaan dalam seluruh prilaku hidupnya, sehingga akan lebih mudah membedakan mana prilaku benar dan yang mana prilaku tidak benar.

\section{Hubungan Pengetahuan dengan Tindakan Pencegahan Covid-19}

Hasil penelitian ini menunjukan terdapat hubungan yang signifikan antara pengetahuan mengenai Covid-19 dengan tindakan pencegahan Covid-19. Penelitian ini sejalan dengan penelitian sebelumnya oleh Nuryani dan Ramadhani (2020) dengan menggunakan analisis korelasi menemukan hubungan yang positif antara pengetahuan dengan perilaku pencegahan Covid-19. Berdasarkan uji bivariat sebanyak 97,4\% responden pada penelitian ini memiliki pengetahuan mengenai Covid-19 yang baik dan memiliki 
tindakan pencegahan Covid-19 yang baik, penelitian ini sejalan dengan penelitian Soeratinoyo dkk (2021) yang melihat pengetahuan dan tindakan pencegahan penyebaran Covid-19 dimana 87\% responden yang memiliki pengetahuan baik memiliki tindakan pencegahan Covid-19 yang baik.

\section{KESIMPULAN}

Ada hubungan yang signifikan antara tingkat pendidikan dengan tindakan pencegahan penularan Covid-19. Ada hubungan yang signifikan antara pengetahuan masyarakat mengenai Covid-19 dengan tindakan pencegahan penularan Covid-19. Peneliti mengucapkan terima kasih sebesar-besarnya kepada Kementerian Pendidikan Kebudayaan Riset dan Teknologi/Badan Riset dan Inovasi Nasional yang telah mendanai penelitian ini sehingga penelitian ini dapat terlaksanakan.

\section{DAFTAR PUSTAKA}

Al Amin, M. 2017. Klasifikasi Kelompok Umur Manusia Berdasarkan Analisis Dimensi Fraktal Box Counting Dari Citra Wajah Dengan Deteksi Tepi Canny. MATHunesa (Jurnal Ilmiah Matematika).

Dinkes Provinsi Sulawesi Utara. Kondisi epidemiologis covid-19 sulawesi utara 25 oktober 2020. https://dinkes.sulutprov.go.id/

Khairunisa Z., Sofia R., Magfirah. 2020. Hubungan Karakteristik Dan Tingkat Pengetahuan Dengan Perilaku Pencegahan Covid-19pada Masyarakat Desa Paya Bujok Blang Pase Kota Langsa. Jurnal Averrous Volume 6 No.1 Mei 2021

Ladaria Y. H., Lumintang J., dan Paat C. J. 2020. Kajian Sosiologi Tentang Tingkat Kesadaran Pendidikan Pada Masyarakat Desa Labuan Kapelak Kecamatan Banggai Selatan Kabupaten Banggai Laut. Jurnal Holistik. Vol. 13 No. 2 / April - Juni 2020

Muhtar, M., Aniharyati, A., \& Ahmad, A. (2020). Pelaksanaan Budaya Keselamatan Pasien pada Masa Pandemi Covid-19 di Rumah Sakit Umum Daerah Bima. Bima Nursing Journal, 2(1), 55-61.

Mujiburrahman, Riyadi M. E., dan Ningsih M. U. 2021. Pengetahuan Berhubungan dengan Peningkatan Perilaku Pencegahan COVID-19 di Masyarakat. Jurnal Keperawatan Terpadu. Vol 2, No 2. Hal 130-140

Moudy I., dan Syakurah R. A. 2020. Pengetahuan terkait Usaha Pencegahan Coronavirus Disease (COVID-19) di Indonesia

Nuryani dan Ramadhani F. 2020. Pengetahuan Berkorelasi Positif dengan Perilaku Pencegahan Covid-19 pada Mahasiswa di Gorontalo. Jurnal Ilmiah Kesehatan. Vol 2, No 3, pp 108-117

Omah, Felix I., Famuwagun, Samuel O. 2020. Knowledge, Perception and Response Study on COVID-19 Community Spread among World Population

Pradono J., dan Sulistyowati N. 2013. Hubungan ANTARA Tingkat Pendidikan, Pengetahuan Tentang Kesehatan Lingkungan, Perilaku Hidup Sehat Dengan Status Ke. Pusat Teknologi Intervensi Kesehatan Masyarakat, Badan Litbang Kesehatan, Kemenkes RI, Jl. Percetakan Negara 29 Jakarta. Alamat Korespondensi: .jpradono@yahoo.com. Hal 89- 95

Purana I. M. 2017. Pengaruh Tingkat Pendidikan Terhadap Perilaku Primordialisme. Jurnal Kajian Pendidikan Widya Accarya FKIP Universitas Dwijendra. ISSN NO. 2085-0018 Maret 2017

Puspitasari N. N. Y., dan Septimar Z. M. 2021. Hubungan Sikap Dengan Perilaku Masyarakat Terhadap 
Pencegahan Covid 19 Di Kecamatan Karawaci Tahun 2020. Jurnal Health Sains. Vol. 2, No. 6. 2548-1398.

Santoso P., dan Setyowati N. 2020. Hubungan Tingkat Pengetahuan Masyarakat Dengan Tindakan Preventif Covid-19. Jurnal Keperawatan Jiwa Volume 8 No 4, November 2020, Hal 565 - 570

Satgas Covid-19 Nasional. Data Sebaran Covid-19. https://covid19.go.id/

Satgas Covid-19 Provinsi Sulawesi Utara. Kasus Konfirmasi. https://corona.sulutprov.go.id/

Sulistyawati S., Rokhmayanti R., Aji B., Wijayanti S. P. M., Hastuti S. K. W., Sukesi T. W., dan Mulasari S. A. Knowledge, Attitudes, Practices and Information Needs During the COVID-19 Pandemic in Indonesia. Risk Management and Healthcare Policy 2021:14 163-17

Sukesih, Maiza L., dan Sopyan A. 2021. Tingkat Pendidikan Dan Pengetahuan Dengan Perilaku Upaya Pencegahan Covid-19 Pada Masyarakat. The $13^{\text {th }}$ University Research Colloqium 2021 Sekolah Tinggi Ilmu Kesehatan Muhammadiyah Klaten.

Soeratinoyo D. K., Doda D. V. D., dan Warouw V. 2021. Hubungan antara Pengetahuan dan Sikap dengan Tindakan Pencegahan Penyebaran COVID-19 pada Perusahaan Produsen Air Minum Dalam Kemasan. Jurnal Biomedik. 2021;13(3):000-000

WHO. 2020. Archived: WHO Timeline - COVID-19. https://www.who.int/news/item/27-04- 2020-whotimeline---covid-19

WHO. 2020. Situation by Country, Territory \& Area. https://covid19.who.int/table

Yunus M., dan Zakaria S. 2021. Sumber Informasi Berhubungan Dengan Pengetahuan Masyarakat Tentang Covid-19. Jurnal Keperawatan. Volume 13, Hal. 337-342 